CENDEKIA, Vol. 13. No. 1 April 2019

p-ISSN: 1978-2098; e-ISSN: 2407-8557

Https://soloclcs.org; Email: cendekiaoslo@gmail.com

Center of Language and Cultural Studies, Surakarta, Indonesia

Winarti, Agus. 2019. Pelatihan Kewirausahaan Perempuan Memberdayakan Masyarakat

Pasca Bencana Alam. Cendekia (2019), 13(1): 67-74. Htpps://doi.org/10.30957/cendekia.v13i1.249.

\title{
Pelatihan Kewirausahaan Perempuan Memberdayaan Masyarakat Pasca Bencana Alam
}

\author{
Agus Winarti \\ Universitas Bandung Raya dpm. \\ Universitas Insan Cendekia Mandiri \\ Jl. Banten 11 Bandung \\ Email: aguswinarti56@gmail.com
}

\begin{abstract}
Training is a process that aims to improve the skills and abilities beyond the prevailing education system, to a person, group or community. The training program is expected to revive the economy after the Merapi disaster victims. Problems faced by the community is the loss of livelihood as a farmer who is the foundation of life for their families devastated swept lava and hot clouds (wedus trash) trim. The purpose of this training is for the empowerment of the people who lost their livelihoods from farming to switch professions as entrepreneurial as the target is an adult female. In the process of development is necessary that adult women are empowered to the fullest, so what is the purpose in meeting the needs of family life can be fulfilled in line with expectations. Women with entrepreneurial training, can improve the economics of the family. The method used to approach the research and development (R \& D), engineering data collection is done through in-depth interviews, questionnaires, observation and documentation. The results showed the presence of the training have the knowledge, skills, behaviors and attitudes to entrepreneurship in everyday life to be able to support the family economy.
\end{abstract}

Keywords: community empowerment, training, entrepreneurship, family

DOI: doi.org/10.30957/cendekia.v13i1.249.

\section{PENDAHULUAN}

Peningkatan sumber daya manusia sangat diperlukan dalam menunjang kesejahteraan masyarakat, baik fisik maupun mental supaya masyarakat dapat mencapai kualitas hidup lebih baik. Salah satu diantaranya melalui pendidikan, sebab kehidupan dan penghidupan yang sesuai dengan nilai-nilai manusia baik secara individu maupun kelompok mutlak memerlukan bekal kemampuan yang dapat dibentuk melalui jalur pendidikan. Dengan pendidikan diharapkan manusia dapat menghadapi tantangan dimasa-masa yang akan datang serta menjadi manusia cerdas, terampil, mandiri dan bertanggung jawab (sense of responsibility). Sesuai dengan tujuan Pendidikan Nasional sebagaimana tercantum dalam Undang Undang Nomor 20 tahun 2003 tentang Sistem Pendidikan Nasional: 
CENDEKIA, Vol. 13. No. 1 April 2019

p-ISSN: 1978-2098; e-ISSN: 2407-8557

Https://soloclcs.org; Email: cendekiaoslo@gmail.com

Center of Language and Cultural Studies, Surakarta, Indonesia

Winarti, Agus. 2019. Pelatihan Kewirausahaan Perempuan Memberdayakan Masyarakat

Pasca Bencana Alam. Cendekia (2019), 13(1): 67-74. Htpps://doi.org/10.30957/cendekia.v13i1.249.

"Pendidikan nasional bertujuan untuk berkembangnya potensi peserta didik agar menjadi manusia yang beriman dan bertakwa kepada Tuhan Yang Maha Esa, berakhlak mulia, sehat, berilmu, cakap, kreatif, mandiri, dan menjadi warga negara yang demokratis serta bertanggung jawab"

Sejalan dengan tujuan pendidikan nasional, secara lebih khusus dijelaskan pula dalam Undang-Undang tersebut tentang prinsip penyelenggaraan pendidikan itu sendiri bahwa:

"Memberdayakan semua komponen masyarakat berarti pendidikan diselenggarakan oleh pemerintah dan masyarakat dalam suasana kemitraan dan kerjasama yang saling melengkapi dan memperkuat".

Kegiatan yang dapat memberikan manfaat bagi kita semua adalah pendidikan dan pelatihan yang akan membawa kita ke arah perubahan pengetahuan, sikap, perilaku dan nilai-nilai serta ketrampilan yang bermanfaat baik secara pribadi maupun secara kelompok dalam masyarakat. Perubahan tersebut dapat mengantar kita untuk terbuka terhadap kebutuhan-kebutuhan yang makin bervariasi dan memberi jalan kearah pemenuhannya.

Pemberdayaan masyarakat menekankan partisipasi masyarakat untuk menemukenali permasalahan sendiri, mengatasi dengan program kerja yang sesuai dan mengatur penyelenggaraan untuk keberlajutannya. Mubyarto (1984) mendefinisikan partisipasi sebagai kesediaan membantu berhasilnya setiap program sesuai kemampuan setiap orang tanpa berarti mengorbankan kepentingan diri sendiri. Selanjutnya partisipasi ini dibedakan atas partisipasi kolektif dan partisipasi individu.

Dimensi kesejahteraan masyarakat merupakan landasan dalam membangun perekonomian yang mandiri dan handal, terutama dalam menyiapkan suatu tranformasi kemampuan usaha yang memiliki daya saing nasional, di mana berawal dari usaha kecil yang meningkat ke usaha menengah, dan kemudian menjadi usaha besar.

Daerah Istimewa Yogyakarta (DIY) merupakan daerah yang sering mengalami bencana alam Gunung Merapi, yang diketahui paling aktif diseluruh dunia. Seperti yang diketahui, Oktober 2010 lalu Gunung Merapi yang berjarak sekitar 30 kilometer dari Yogyakarta meletus hebat, menewaskan lebih dari 340 jiwa dan memaksa sekitar 200,000 penduduk untuk mengungsi dari desa-desa sekitar lereng gunung. Awan panas dan lahar dingin telah menghancurkan ribuan rumah dan wilayah sekitarnya. Banyak dari penduduk, terutama sekitar Gunung Merapi yang kehilangan pekerjaan rutin kesehariannya sebagai petani (BNPB 5 Des 2011).

Kondisi obyektif kehidupan masyarakat menunjukkan terdapatnya sangat menurunnya kualitas hidup yang bermasalah dan ketidakberdayaan, ketidak berdayaan ini banyak terjadi hampir di semua lapisan masyarakat baik yang tinggal di kota maupun di desa. Hal ini cukup beralasan karena masyarakat merupakan bagian dalam pelaksanaan pembangunan bangsa, merupakan aset dalam bentuk sumber daya manusia yang perlu diberdayakan dan di kembangkan kemampuannya melalui pelatihan kecakapan hidup dan berwirausaha yang dapat segera mendapatkan pendapatan, sementara yang tadinya bertani dikarenakan sudah luluh lantak akibat lahar Gunung 
CENDEKIA, Vol. 13. No. 1 April 2019

p-ISSN: 1978-2098; e-ISSN: 2407-8557

Https://soloclcs.org; Email: cendekiaoslo@gmail.com

Center of Language and Cultural Studies, Surakarta, Indonesia

Winarti, Agus. 2019. Pelatihan Kewirausahaan Perempuan Memberdayakan Masyarakat

Pasca Bencana Alam. Cendekia (2019), 13(1): 67-74. Htpps://doi.org/10.30957/cendekia.v13i1.249.

Merapi. Penelitian ini bertujuan membantu mengembangkan para relawan pemberdayaan masyarakat yang peduli kepada kaum perempuan yang kehilangan matapencaharian atau harus beralih matapencaharian karena erupsi merapi, untuk dapat meningkatkan perekonomian keluarga, sehingga dapat mandiri/ tidak bergantung pada bantuan pemerintah.Metode yang digunakan dalam penelitian ini dengan melakukan pendekatan penelitian dan pengembangan (R\&D), teknik pengumpulan data dilakukan melalui wawancara mendalam, angket, observasi dan dokumentasi. Adapun guna dari penelitian ini membantu memecahkan permasalahan hilangnya pendapatan/ matapencaharian akibat erupsi Merapi yang dihadapi masyarakat, dan instansi pemerintah yang terkait.

Menurut Niehoff, (1977:8) dalam Mustofa Kamil, (2009:14) merumuskan pendidikan nonformal secara terperinci yakni: Nonformal education is definited for our purpose as the mothod of assessing the needs end interests of adults and out-of scool youth in developing cuontries-of communicating with them, motivating them to patterns, and related activities which will increase their productivity and improve their living standard.

Pengungkapan istilah pendidikan nonformal memberikan informasi bahwa pada hakekatnya pendidikan tidak hanya diselenggarakan di pendidikan formal saja, tetapi juga di pendidikan nonformal. Hal ini sesuai dengan Undang-Undang Republik Indonesia No 20 tahun 2003 tentang Sistem Pendidikan Nasional, pasal 1 ayat (10) Satuan pendidikan adalah kelompok layanan pendidikan yang menyelenggarakan pendidikan pada jalur formal, nonformal, dan informal pada setiap jenjang dan jenis pendidikan; ayat (11) Pendidikan formal adalah jalur pendidikan yang terstruktur dan berjenjang yang terdiri atas pendidikan dasar, pendidikan menengah, dan pendidikan tinggi; ayat (12) Pendidikan nonformal adalah jalur pendidikan di luar pendidikan formal yang dapat dilaksanakan secara terstruktur dan berjenjang; ayat (13) Pendidikan informal adalah jalur prndidikan keluarga dan lingkungan. Berdasarkan pada pernyataan tersebut, maka pendidikan nonformal merupakan salah satu jalur dari penyelenggaraan sistem pendidikan di Indonesia.

\section{METODE}

Pendekatan yang digunakan dalam penelitian ini adalah pendekatan kualitatif (qualitative approach) dan pendekatan kuantitatif (quantitative approach) dengan metode penelitian dan pengembangan (research and Development). Pendekatan ini digunakan karena untuk mengkaji permasalahan dan memperoleh makna yang lebih mendalam di lokasi penelitian yang berkaitan dengan tingkah laku dan kata-kata responden khususnya dalam pemberdayaan masyarakat pasca bencana alam melalui pelatihan kecakapan vokasional untuk bisa mandiri. Penelitian ini akan menghasilkan data deskriptif berupa kata-kata atau pendapat masyarakat dan perilaku yang diamati.

Langkah-langkah penelitian ini adalah penelitian pendahuluan, pengembangan konseptual, dan eksperimen. Sedangkan subyek penelitian masyarakat pasca bencana khususnya kaum perempuan. Untuk memperoleh data yang akurat, diperlukan teknik pengumpulan data yang sesuai dengan karakteristik penelitian kualitatif, maka teknik pengumpulan data dilakukan dengan: (1) studi dokumentasi, (2) observasi (pastisipasif 
CENDEKIA, Vol. 13. No. 1 April 2019

p-ISSN: 1978-2098; e-ISSN: 2407-8557

Https://soloclcs.org; Email: cendekiaoslo@gmail.com

Center of Language and Cultural Studies, Surakarta, Indonesia

Winarti, Agus. 2019. Pelatihan Kewirausahaan Perempuan Memberdayakan Masyarakat

Pasca Bencana Alam. Cendekia (2019), 13(1): 67-74. Htpps://doi.org/10.30957/cendekia.v13i1.249.

dan non pastisipasif), (3) wawancara mendalam, (4) diskusi kelompok terfokus (FGD), dan (5) asesmen partisipatori (Partisipatory Rural Appraisal- PRA) pre test sebelum mengadakan eksperimen dan tes akhir setelah melaksanakan pelatihan.Teknik analisa data dengan cara analisa kualitatif, analisa kuntitatif analisis statistic non parametric melalui uji Wilcoxon (Wilcoxon Test).

\section{HASIL DAN PEMBAHASAN}

\subsection{Pemberdayaan Masyarakat Melalui Pelatihan}

Pemberdayaan adalah suatu proses peningkatan masyarakat pada umumnya, baik dalam ketrampilan untuk hidup, maupun ketrampilan berusaha bersama, melalui pelatihan kewirausahaan bagi perempuan. Pemberdayaan menurut Kindervatter (1979:13) adalah "people gaining an understanding of and control over social, economic, and/or political forces in order to improve their standing in society". Dalam tulisan ini hasil penelitian, yang dimaksud Pendidikan Luar Sekolah sebagai pemberdayaan menurut Engking Soewarman Hasan (2000:24) adalah pendekatan pendidikan yang membuat siswa memperoleh pemahaman yang lebih besar mengenai sosial, ekonomi serta politis, melalui:1) latihan terus menerus mengenai semua aspek yang berhubungan dengan proses belajar, 2) mempelajari keahlian yang responsif terhadap kebutuhanya, 3) bekerjsama secara kolaborasi untuk menyelesaikan masalah yang timbul.

Selanjutnya akan diungkapkan mengenai tujuan pelatihan, yang dikemukakan oleh berbagai ahli, antara lain: Sudjana (2005:105) mengatakan bahwa "tujuan pelatihan adalah deskripsi tentang perilaku yang diharapkan dapat dicapai oleh peserta pelatihan setelah mengikuti pelatihan". Sedangkan Mayer (Sudjana, 2005: 105) mengatakan bahwa "tujuan pelatihan adalah pernyataan yang menguraikan sesuatu perubahan yang diusulkan akan terjadi pada diri peserta pelatihan, yaitu perubahan setelah peserta pelatihan menyelesaikan pengalaman belajar dalam pelatihan".

Menurut Laird.D (1995) The fungtion once known as "training" has had to expand its own technology. It has had toblocate and implement non-training solutions for all thoso performance problems which are not caused by not knowing how. Later on we can look at these "other problema and other solutions" in detail. ( Laird.D; 1995:10).

Bahwa pelatihan merupakan solusi yang sangat tepat bagi "Performance problem" yang disebabkan oleh faktor pengetahuan, ketrampilan individu yang kurang memadai bagi yang bersangkutan dalam menjalankan tugasnya. Perubahan-perubahan yang mengakibatkan oleh suatu masalah harus segera dipecahkan, sedangkan aspirasi cenderung kepada tahap pertumbuhan untuk adanya nilai tambah. Moekijat mengungkapkan: Dengan pelatihan adalah suatu bagian pendidikan yang menyangkut proses belajar untuk memperoleh dan meningkatkan ketrampilan di luar system pendidikan yang berlaku, dalam waktu yang relatif singkat dan dengan metode yang lebih mengutamakan praktek daripada teori.

Latihan ketrampilan yang diberikan bagi perempuan meliputi pemberian ketrampilan memasak, mengolah sumber daya lokal seperti ubi kayu menjadi makanan setengah jadi (kecimpring, emping dari ubi berbagai rasa: pedas manis, rasa bawang, 
CENDEKIA, Vol. 13. No. 1 April 2019

p-ISSN: 1978-2098; e-ISSN: 2407-8557

Https://soloclcs.org; Email: cendekiaoslo@gmail.com

Center of Language and Cultural Studies, Surakarta, Indonesia

Winarti, Agus. 2019. Pelatihan Kewirausahaan Perempuan Memberdayakan Masyarakat

Pasca Bencana Alam. Cendekia (2019), 13(1): 67-74. Htpps://doi.org/10.30957/cendekia.v13i1.249.

kerupuk aci membuat kerajinan dari manik-manik dan pemanfaatan barang bekas). Masing-masing program memakan waktu pelatihan yang berbeda-beda, selain itu lama tidaknya pelatihan juga disesuaikan dengan kemampuan masing-masing individu dalam menangkap dan memahami pelatihan yang diberikan. Pelatihan diselenggarakan dengan menggunakan metode demonstrasi yaitu dengan memperlihatkan setiap kegiatan pelatihan tahap demi tahap kepada peserta pelatihan dan partisipatif aktif setiap peserta pelatihan dimana peserta mempunyai hak dan kedudukan yang sama untuk ikut berperan aktif dan memilih jenis ketrampilan atau kegiatan yang sesuai dengan minatnya, hal ini tidak menutup kemungkinan bagi klien apabila ia ingin mengikuti keseluruhan pelatihan ketrampilan yang diberikan.

Pendidikan kecakapan hidup adalah, untuk meningkatkan keterampilan, pengetahuan dan sikap warga belajar dibidang pekerjaan atau usaha tertentu sesuai dengan bakat dan minatnya sehingga mereka memiliki bekal kemampuan untuk bekerja atau berusaha mandiri untuk meningkatkan kualitas hidupnya. Selain itu kondisi peserta pelatihan masih belum stabil/trauma dengan terjadinya bencana alam yaitu gempa gunung merapi yang meluluh lantakkan semua harta benda, lahan pertanian bahkan anggota keluarganya, dengan adanya pelatihan kecakapan hidup masyarakat termotivasi menemukan kembali semangat hidup dan menata kembali kehidupannya dari keterpurukan.

Sasaran program pendidikan kecakapan hidup dalam pendidikan non formal adalah: (1) Warga belajar dari berasal dari keluarga yang kurang mampu dan masyrakat lain yang tidak memiliki keterampilan untuk bekal hidupnya, yang ingin belajar untuk meningkatkan keterampilan guna meningkatkan taraf hidupnya, (2) fasilitator atau tutor terdiri dari orang-orang yang mempunyai keterampilan dan punya sifat kepedulian terhadap masyarakat yang kurang mampu, (3) kurikulum pembelajran bersifat fleksibel dan harus disesuaikan dengan kebutuhan warga belajar, proses pembelajarannya berlangsung dalam waktu singkat, tidak harus berjenjang dan berkesinambungan. Pembelajaran praktik lebih banyak dibandingkan teori, (4) metode pembelajarannya bersifat dialogis, partisipatif dan andragogis, artinya belajar dan bekerja menyatu dalam proses pembelajaran, (5) keberhasilan pembelajaran diukur dari peningkatan pengetahuan dan keterampilan yang dimiliki oleh warga belajar. Peranan dan fungsi serta tugas dari pendidikan non-formal adalah mempersiapkan warga belajar agar mampu: mengembangkan kehidupan sebagai pribadi, masyarakat, bernegara dan bangsa. Serta mempersiapkan warga belajar mampu meningkatkan kualitas hidup bagi keluarganya.

\subsection{Penyebab Terjadinya Kemiskinan}

Kemiskinan yang terjadi di masyarakat juga lebih disebabkan oleh keterbatasan kesempatan dan kemampuan dari masyarakat itu sendiri, sehingga menjadi tidak berdaya. Ketidakberdayaan ini banyak terjadi hampir di semua lapisan masyarakat baik yang tinggal diperkotaan maupun dipedesaan. Apalagi ketidakberdayaan yang dialami masyarakat tidak saja menimpa kaum tua, akan tetapi banyak juga menimpa para generasi muda dan kaum perempuan. 
CENDEKIA, Vol. 13. No. 1 April 2019

p-ISSN: 1978-2098; e-ISSN: 2407-8557

Https://soloclcs.org; Email: cendekiaoslo@gmail.com

Center of Language and Cultural Studies, Surakarta, Indonesia

Winarti, Agus. 2019. Pelatihan Kewirausahaan Perempuan Memberdayakan Masyarakat

Pasca Bencana Alam. Cendekia (2019), 13(1): 67-74. Htpps://doi.org/10.30957/cendekia.v13i1.249.

Di samping itu ketidak berdayaan masyarakat juga disebabkan kebijakan dan strategi pembangunan ekonomi yang ditempuh selama ini hanya mengacu pada pertumbuhan (growth) dan pengelolaan ekonomi nasional hanya dipercayakan kepada sekelompok orang atau para konglomerat sebagai engine of growth, sementara sektor industry rumah tangga seperti kerajinan dan usaha kecil lainnya menempati posisi marjinal. Padahal kita cermati pada saat terjadinya lahar merapi menerjang Daerah Istimewa Yogyakarta merupakan sektor usaha kecil menjadi penyelamat perekonomian DIY khususnya di Kabupaten Sleman.

Pemberdayaan masyarakat melalui pelatihan kewirausahaan perempuan untuk meningkatkan ekonomi keluarga pasca gempa. Untuk memenuhi kebutuhan sehari-hari melalui kegiatan berusaha, perlunya sebuah pemikiran tentang model pelatihan kewirausahaan perempuan yang dapat mengakomodasi kebutuhan para perempuan yang kehilangan mata pencaharian atau harus beralih mata pencaharian dari sebelum terjadinya erupsi merapi. Dari hasil penelitian diharapkan kaum perempuan yang mendapatkan pelatihan mampu mengembangkan secara terus menerus dan berkelanjutan. Untuk kepentingan tersebut kiranya pemberdayaan masyarakat melalui pelatihan kewirausahaan perempuan akan mampu meningkatkan kemampuan mereka untuk memenuhi kebutuhan keluarga, karena melalui pelatihan kewirausahaan perempuan diharapkan antar perempuan sebagai warga belajar akan dapat berperan aktif dan bekerjasama dalam setiap kegiatan dalam Huntara (hunian sementara).

Pasca bencana alam lebih sering banyak permasalahan ketimbang pada saat bencana itu terjadi. Masih ada yang lebih serius lagi, yaitu rendahnya tingkat pendapatan masyarakat wilayah rawan bencana yang kebanyakan berada di desa. Kelompok masyarakat ini termasuk dalam kategori paling terpukul atas terjadinya bencana. Penangan pasca bencana bukan lagi menjadi tanggung jawab pemerintah tetapi menjadi urusan bersama dengan masyarakat. Mengingat kondisi wilayah Indonesia merupakan wilayah rawan bencana dan perlu membantu masyarakat dalam menghadapi permasalahan pasca bencana alam.

Dalam konteks penelitian yang dilakukan, pemberdayaan masyarakat pasca bencana alam dapat diartikan sebagai suatu upaya bersama dan terencana untuk meningkatkan kualitas hidup masyarakat dalam menghadapi permasalahan pasca bencana alam. Untuk mencapai tujuan tersebut masyarakat perlu diberikan motivasi, kekuatan, pengetahuan dan keterampilan agar mampu menanggulangi permasalahan pasca bencana alam. Baik bencana yang telah berlalu maupun benca-bencana lain yang kemungkinan mengancam masyarakat yang tinggal di kawasan rawan bencana.

Agar masyarakat berdaya, pembelajaran masyarakat merupakan salah satu solusi yang memberikan ruang pada masyarakat untuk berpartisipasi dalam kegiatan pembelajaran. Peningkatan peran masyarakat dalam pembangunan tersebut dapat tercapai apabila masyarakat telah diberdayakan melalui pemberian pengetahuan dan kecakapan vokasional untuk meningkatkan kemandirian masyarakat. Melihat kenyataan yang demikian, maka diperlukan program pemberdayaan yang tidak saja melihat dari segi prosesnya saja, tetapi sampai kepada hasil.

Pelaksanaan program pemberdayaan yang ditujukan kepada masyarakat pasca bencana alam yang tinggal dihunian sementara, bertujuan agar masyarakat dapat 
CENDEKIA, Vol. 13. No. 1 April 2019

p-ISSN: 1978-2098; e-ISSN: 2407-8557

Https://soloclcs.org; Email: cendekiaoslo@gmail.com

Center of Language and Cultural Studies, Surakarta, Indonesia

Winarti, Agus. 2019. Pelatihan Kewirausahaan Perempuan Memberdayakan Masyarakat

Pasca Bencana Alam. Cendekia (2019), 13(1): 67-74. Htpps://doi.org/10.30957/cendekia.v13i1.249.

bersama-sama saling belajar, saling asah, saling asih, saling asuh, dalam upaya mencapai tujuan yang sama, yaitu memiliki mata pencaharian baru. Dengan dimilikinya mata pencaharian baru, masyarakat akan mampu meningkatkan kesejahteraan yang pada gilirannya dapat meningkatkan kemandirin. Tujuan ini sejalan dengan ungkapan yang diadaptasi dari Sakya (1986:8) dalam UNESCO (1993), yaitu, maksud dari penyelenggaraan program pemberdayaan melalui pelatihan adalah untuk; (a) memberikan kecakapan vokasional; (b) mengajarkan keterampilan baru; (c) memperoleh informasi baru untuk memperbaiki kualitas hidup; (d) menumbuhkan kesadaran kritis tentang peristiwa mutakhir di lingkungannya; (e) membantu mengembangkan sikap rasional dan ilmiah; (f) mengorientasikn pada nilai-nilai dan sikap baru yang dibutuhkan dalam pembangnan; dan (g) untuk hiburan dan kegembiraan/melepaskan beban dari trauma.

Masyarakat pasca bencana alam yang berada hunian sementara sebagian besar menjadi pengangguran mendadak. Dengan demikian masyarakat ini perlu mendapat perhatian untuk segera diberdayakan, agar memiliki ketrampilan yang dapat dijadikan sebagai mata pencaharian baru. Masyarakat umumnya pada usia produktif dan memiliki potensi yang dapat dikembangkan. Untuk itu perlu dilakukan upaya-upaya pemberdayaan untuk memperbaiki taraf hidupnya.

Dari hasil penilaian pada ketiga aspek pengetahuan, keterampilan dan sikap dapat diketahui bahwa program pelatihan selain telah mampu meningkatkan pengetahuan dan keterampilan peserta pelatihan, juga telah mampu merubah sikap kearah yang lebih mandiri. Secara kuantitatif ditemukan bahwa jenjang terkecil dari masing-masing aspek yang dihitung tetap menunjukkan nilai 0 . Dengan demikian dari tabel kritis Uji Wilcoxon untuk $\mathrm{n}=32$, dengan kesalahan $\alpha \quad 0,05$ maka $\mathrm{t}$ tabel $=159$. Karena jenjang terkecil adalah 0, dan ternyata lebih kecil dari 159. Maka terdapat peningkatan baik pengetahuan, penguasaan keterampilan maupun perubahan sikap dari peserta pelatihan antara sebelum dan sesudah mengikuti pelatihan. Dari hasil analisis secara keseluruhan dapat dimaknai bahwa pelatihan kewirausahaan perempuan untuk meningkatkan perekonomian masyarakat pasca bencana alam, ternyata cukup efektif dalam memberikan perubahan positif pada masyarakat.

Hasil penelitian menunjukkan bahwa meningkatnya pengetahuan, keterampilan dan perubahan sikap peserta pelatihan yang diperoleh dari perbedaan hasil pre-test dan post-test, bermakna ternyata memberikan pengaruh positif terhadap perubahan peningkatkan ekonomi dalam keluarganya, dimana efek dari pelatihan kewirausahaan bagi perempuan untuk meningkatkan perekonomian keluarga yang di kembangkan memberikan dampak positif.

Dalam penelitian pelatihan kewirausahaan perempuan untuk meningkatkan perekonomian keluarga pasca bencana alam peneliti menggunakan sejumlah 32 orang sebagai peserta, dari hasil kualitatif dan kuantitatif sebagaimana telah di bahas sebelumnya, secara kualitatif temuan penelitian menunjukkan bahwa peserta pelatihan mampu diberdayakan melalui kegiatan pelatihan untuk meningkatkan perekonomian keluarga, Temuan dan analisis kualitatif ini diperkuat dengan temuan kuantitatif. Hasil dari analisis kuantitatif menunjukkan telah terjadi perbedaan secara nyata antara pengatahuan dan kemampuan peserta sebelum dan sesudah mengikuti pelatihan, 
CENDEKIA, Vol. 13. No. 1 April 2019

p-ISSN: 1978-2098; e-ISSN: 2407-8557

Https://soloclcs.org; Email: cendekiaoslo@gmail.com

Center of Language and Cultural Studies, Surakarta, Indonesia

Winarti, Agus. 2019. Pelatihan Kewirausahaan Perempuan Memberdayakan Masyarakat

Pasca Bencana Alam. Cendekia (2019), 13(1): 67-74. Htpps://doi.org/10.30957/cendekia.v13i1.249.

sehingga dapat dimaknai bahwa pelatihan kewirausahaan perempuan untuk meningkatkan perekonomian keluarga pasca bencana alam teruji efektif dalam memberdayakan peserta untuk menguasai pengetahuan, keterampilan sehingga merubah sikap lebih mandiri.

\section{SIMPULAN}

Permasalahan yang ditemukan di lapangan, ketidakberdayaan terjadi karena kebutuhan mendasar, primair seperti pangan, kebutuhan sekunder seperti sandang dan kebutuhan tertiar seperti rumah tidak tersedia. Bencana yang bersifat tiba-tiba bisa merupakan penyebab ketiadaan sarana dan prasarana yang menjaminkan keberlangsungan pemenuhan kebutuhan manusia. Sementara potensi yang masih tersisi dari bencana alam erupsi merapi seperti tanaman ubi kayu sebagian padi dan salah. Potensi inilah yang dapat memberikan peluang ubntuk dapat diolah menjadi lebih baik dan memberikan kegiatan bagi masyarakat menjadi bahan makan setengah jadi atau makanan jadi seperti: kecimpring, emping ubi kayu, krupuk aci.

Kebutuhan yang diperlukan bagi masyarakat memerlukan bentuk ketrampilan untuk dapat mengolah bahan makanan yang tersedia/ potensi lokal dengan memberikan pelatihan ketrampilan vokasional bagi masyarakat setempat, sampai mampu memasarkan dan memperoleh pendapatan yang pada akhirnya dapat meningkatkan kesejahteraan keluarga. Usaha inilah yang dapat dilakukan oleh kaum perempuan dan cocok bagi masyarakat pasca bencana alam. Dengan demikian menjadi konsep pemberdayaan masyarakat melalui pelatihan kewirausahaan perempuan dapat meningkatkan ekonomi keluarga pasca bencana alam erupsi merapi.

\section{DAFTAR PUSTAKA}

Kindervatter, S. (1979). Non Formal Education: As an Empowering Process, Amerika Serikat: Printer in The Unitet States of America.

Laird, Dugan. (1995), Approaches to Training and Development. USA: AddisonWesley Publishing Company.

Mustofa Kamil., (2009). Pendidikan Nonformal Pengembangnan melalui pusat Kegiatan Belajar Mengajar (PKBM) Di Indonesia (Sebuah Pembelajaran dari Kominkan Jepang),Bandung: Alfabet.

Mustofa, Kamil. (2010). Model pendidikan dan pelatihan (Konsep dan Aplikasi), Bandung: Alfabeta.

Mubyarto. (1984), Strategi Pembangunan Pedesaan, P3PK UGM Yogyakarta

Sudjana, D., (2001). Pendidikan Luar Sekolah, Wawasan Sejarah Perkembangan Falsafah Teori Pendukung Asas, Bandung: Falah Production.

Sudjana, D. (2007). Sistem dan Manajemen Pelatihan Teori dan Praktek, Bandung: Falah Production.

Sudjana, D. (2010). Metode dan Teknik Pembelajaran Partisipasif, Bandung: Falah Production 